Vol. 6 (1997): 399-408.

\title{
Grain yield, net blotch and scald of barley in Finnish official variety trials
}

Jonathan Robinson

Agricultural Research Centre of Finland, Institute of Crop and Soil Science, Plant Breeding Section, FIN-31600 Jokioinen, Finland, e-mail: jonathan.robinson@mtt.fi

Marja Jalli

Agricultural Research Centre of Finland, Institute of Crop Protection, Plant Pathology Section, FIN-31600 Jokioinen, Finland

\begin{abstract}
Data on grain yield, and terminal severity of net blotch (Pyrenophora teres f. teres) and scald (Rhynchosporium secalis) from Finnish official barley (Hordeum vulgare) variety trials were analysed to indicate the pattern of disease incidence over six years and five sites for nineteen barley genotypes, and the effect of the diseases on yield and the genotype by environment interaction for yield. The effect of climatic factors on net blotch severity were also investigated. The genotype by site interaction for net blotch severity was not statistically significant, but that for yield was. Net blotch severity differed between years, but was similar across sites and there were statistically significant first order interactions between year, site and genotype. 'Saana' and 'Thule' had relatively low mean terminal net blotch scores and their reaction to the disease was less sensitive to the environment than was that of 'Tyra' for example. Analysis of yield data adjusted for net blotch severity indicated that the magnitude of the genotype by environment interaction terms were not accounted for to any significant degree by differences in relative net blotch resistances among the barley genotypes. Overall, mean scores for scald severity were lower than those for net blotch. Terminal net blotch severity was correlated with May rainfall and growing degree days.
\end{abstract}

Key words: Foliar diseases, genotype by environment interaction Hordeum vulgare, Pyrenophora teres, Rhynchosporium secalis

\section{Introduction}

Net blotch, caused by the fungus Pyrenophora teres Drechs. $f$. teres Smedeg., and scald, caused by the fungus Rhynchosporium secalis (Oud.) J.J.
Davis, are the two principal pathogens of barley, Hordeum vulgare L., in Finland (Mäkelä 1974, Mäkelä 1975). Both diseases have a worldwide distribution and importance, and deployment of barley cultivars resistant to these diseases has been a priority in many barley breed- 


\section{Robinson, J. \& Jalli, M. Grain yield, net blotch and scald of barley}

ing programmes (Shipton et al. 1973, Shipton et al. 1974, Vivar et al. 1987). Robinson and Jalli (1996) and Robinson et al. (1996) indicated that in Finland, under artificially induced epidemics of net blotch and scald, there were small reductions in grain yield and reductions in quality characteristics of the grain. Little is known about the effects of naturally occurring epidemics of the diseases on barley grain yield in Finland. Scald is reported to cause very severe yield loss in Norway (Ringlund and Bjørnstad, pers. comm.) and natural epidemics of net blotch can cause up to $40 \%$ yield loss (Mathre 1982).

In Finland data have been compiled on the disease reaction and grain yield of many barley genotypes grown in a range of environments (sites and years). Using data from official variety trials, the objectives of the investigations reported here were to establish the nature of the infection pattern for net blotch and scald over various environments for a range of spring barleys, including both six and two-row genotypes. In conjunction with data for yield recorded from the same trials, an attempt was made to establish if the genotype by environment interactions for yield could be accounted for in terms of the differential effects of disease resistances among the barley genotypes included in the study. Baker (1971) demonstrated that stem rust, Puccinia graminis Pers. f. sp. tritici, and leaf rust, Puccinia recondita Rob. Ex. Des., infection of wheat, Triticum aestivum L., in Canada were important considerations in estimating the genotype by environment interaction for yield. Nissilä (1996) indicated that disease resistance of barley in Finland had an apparent influence on the relationship between the phenotype and genotype by environment interactions for yield under stress conditions.

Early summer droughts frequently reduce barley yields in southern Finland (Mukula 1988, Mukula and Rantanen 1989), but the climatic conditions promoting disease development in barley have not been investigated. An additional aim of the work reported here was to establish the effect of rainfall and growing degree days (GDD) on terminal net blotch severity.

\section{Material and methods}

Data on mean grain yields and mean net blotch and scald severities were analysed for 19 Nordic spring barley genotypes grown in replicated (2-4 replicate blocks) official variety trials at five sites over six years (1991 to 1996). All trials were sown in May and fungicide seed dressing was discontinued beyond 1991. One site-year combination was missing (sat 1996) and datasets were not completely balanced. The sites included, sat $\left(61^{\circ} 16^{\prime} \mathrm{N}\right)$, epo $\left(62^{\circ} 56^{\prime} \mathrm{N}\right)$, esa $\left(61^{\circ} 44^{\prime} \mathrm{N}\right)$, hja $\left(60^{\circ} 25^{\prime} \mathrm{N}\right)$ and lou $\left(60^{\circ} 38^{\prime} \mathrm{N}\right)$. The barley material included the six-row genotypes, 'Arra', 'Arttu', 'Arve', 'Botnia', Hja 87061, Jo 1632, 'Loviisa', 'Pohto', 'Pokko', and 'Thule', and the tworow genotypes, 'Filippa', 'Inari', 'Kinnan', 'Kustaa', 'Kymppi', 'Mette', 'Saana', 'Tyra' and 'Viivi'. The foliar disease severities, arising from natural epidemics, were assessed at around GS 60 (Tottman and Makepeace 1979) for entire plots according to Saari and Prescott (1975) on a scale from zero to ten, where zero indicates no infection, and ten indicates extreme susceptibility, with severe infection on all leaves. Climatic data, daily rainfall and GDD $>0{ }^{\circ} \mathrm{C}$ (Saarikko and Carter 1996), were taken from the central database at the Agricultural Research Centre of Finland.

Analyses of variance of grain yield and net blotch data were done on means over replicates using PROC GLM (SAS Institute 1989). Covariance analysis of yield data adjusted for terminal net blotch severity was done using the same procedure. The second order interaction, genotype by site by year, was used as the error term for gauging the genotype main effect and interaction terms. The year by site interaction was used as the error term in assessing the significance of the site and year main effects. Stability (sensitivity) analyses for the net blotch data were done according to Finlay and Wilkinson (1963), following establishment of statistical significance of interaction terms, with mean net blotch scores plotted against environmental means, and regression coefficients plotted against genotype means across environments. 
Vol. 6 (1997): 399-408.

Regression analyses for climatic data and net blotch terminal severities, and homogeneity of slopes and intercepts, were determined using PROC REG (SAS Institute 1989) and PROC GLM (Littell et al. 1991). Components of variance were determined with PROC VARCOMP (SAS Institute 1989).

\section{Results}

The plot of mean barley grain yields from the five sites over six years reveals considerable differences in yields associated with site and year (Fig. 1). There is, however, a discernible general pattern of yields at the five sites; a drop in yield between 1991 and 1992, with a subsequent increase in 1993, followed by a slight fall in 1994. A similar plot for terminal net blotch infection (Fig. 2) indicates a pattern virtually consistent at sites over years, with a drop in infection from 1991 to 1992 , followed by a levelling off and a subsequent steady rise in infection levels up to 1996. There is no immediate evidence, however, of a simple relationship between net blotch and yield from comparison of Figures 1 and 2. The plot for scald incidence (Fig. 3) is very different to that for net blotch. The disease was only evident at two sites (lou and epo), and varied greatly in incidence and severity among years at those sites. Again, there is no obvious relationship between scald incidence and yield, nor between scald and net blotch incidence.

The results of analyses of variance of yield and net blotch data are given in Table 1; analysis of data for scald incidence were omitted because of low diseases incidence at most locations. It is apparent that for yield, all first order interactions between genotype, site and year are highly significant, the year by site interaction having the largest mean square. The main effect of site was not statistically significant and the annual variation was only significant at $\mathrm{P}<0.05$. For net blotch, the site effect was again not statistically significant, but interaction terms, with

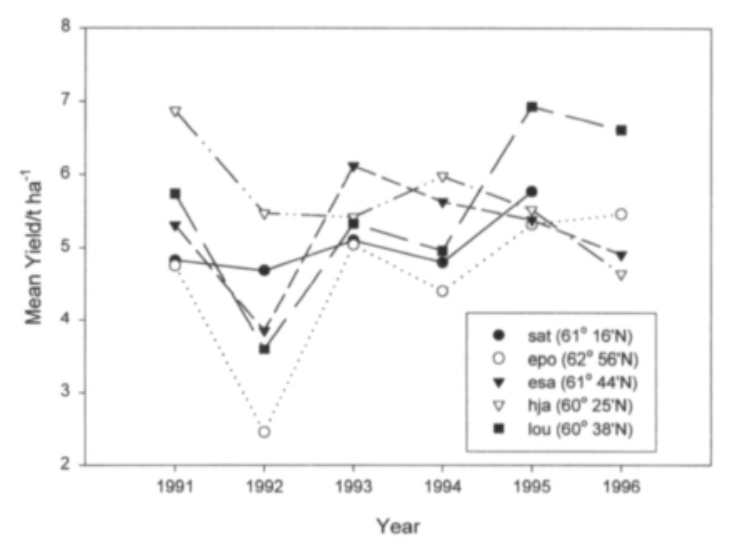

Fig. 1. Mean barley grain yields from 19 spring barley genotypes grown in Finnish official variety trials conducted at five sites over six years.

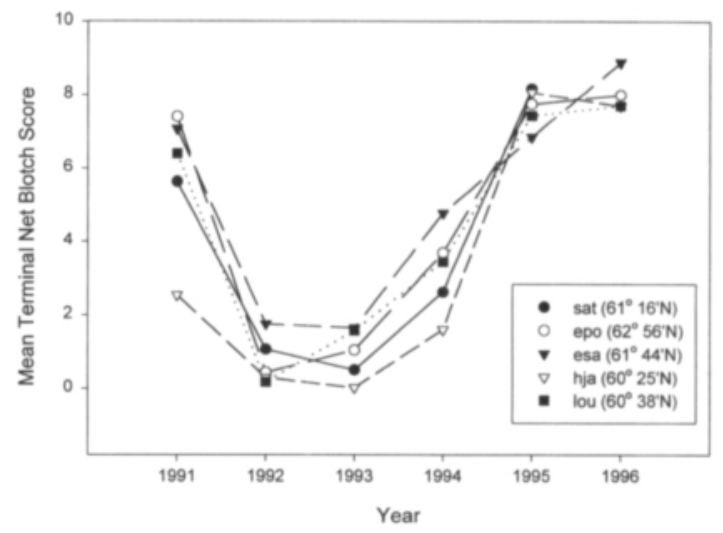

Fig. 2. Mean terminal net blotch severity scores from 19 spring barley genotypes grown in Finnish official variety trials conducted at five sites over six years.



Fig. 3. Mean terminal scald severity scores from 19 spring barley genotypes grown in Finnish official barley variety trials conducted at five sites over six years. 
Robinson, J. \& Jalli, M. Grain yield, net blotch and scald of barley

Table 1. Analyses of variance (degrees of freedom, mean squares and variance ratios) for grain yield and terminal net blotch severity data from 19 barley genotypes grown in Finnish official variety trials conducted at five sites over six years, and of yield data with net blotch data used as a covariate.

\begin{tabular}{|c|c|c|c|c|c|c|c|c|c|}
\hline \multirow[b]{2}{*}{ Source } & \multicolumn{3}{|c|}{ Yield } & \multicolumn{3}{|c|}{ Net blotch } & \multicolumn{3}{|c|}{$\begin{array}{l}\text { Yield adjusted } \\
\text { for net blotch }\end{array}$} \\
\hline & df & MS & $\mathrm{F}$ & df & MS & $\mathrm{F}$ & df & MS & $\mathrm{F}$ \\
\hline site (s) & 4 & 17.96 & $2.62 \mathrm{~ns}$ & 4 & 34.86 & $2.98 \mathrm{~ns}$ & 4 & 14.39 & $2.18 \mathrm{~ns}$ \\
\hline year $(y)$ & 5 & 21.75 & $3.17 *$ & 5 & 362.67 & $31.03 * * *$ & 5 & 13.32 & $2.02 \mathrm{~ns}$ \\
\hline$y^{*} s$ & 19 & 6.86 & $64.89 * * *$ & 19 & 11.69 & $15.18^{* * *}$ & 19 & 6.59 & $64.99 * * *$ \\
\hline genotype (g) & 18 & 1.26 & $11.92 * * *$ & 18 & 14.05 & $18.24^{* * *}$ & 18 & 1.24 & $12.25^{* * *}$ \\
\hline$g^{*} y$ & 85 & 0.28 & $2.60^{* * *}$ & 83 & 1.50 & $1.95 * * *$ & 83 & 0.26 & $2.56^{* * * *}$ \\
\hline $\mathrm{g} * \mathrm{~s}$ & 72 & 0.35 & $3.31^{* * *}$ & 72 & 0.61 & $0.79 \mathrm{~ns}$ & 72 & 0.34 & $3.31 * * *$ \\
\hline error & 258 & 0.11 & & 253 & 0.77 & & 247 & 0.10 & \\
\hline $\mathrm{n}$ & & 462 & & & 455 & & & 450 & \\
\hline
\end{tabular}

ns, not statistically significant, $\mathrm{P} \geq 0.05 ;{ }^{*},{ }^{* *}, * * *$, statistically significant at $\mathrm{P}<0.05, \mathrm{P}<0.01$ and $\mathrm{P}<0.001$ respectively.

the exception of that for genotype by site, were statistically significant. Analysis of the yield data adjusted for net blotch indicates that neither site nor year terms were statistically significant, but that the remaining terms all reached significance at $\mathrm{P}<0.001$.
Regression of mean net blotch infection scores on environmental means (Fig. 4) indicates considerable crossover interaction (changes in genotype rank over environments), but also shows that 'Arve' had consistently higher symptom scores than all other genotypes over all en-

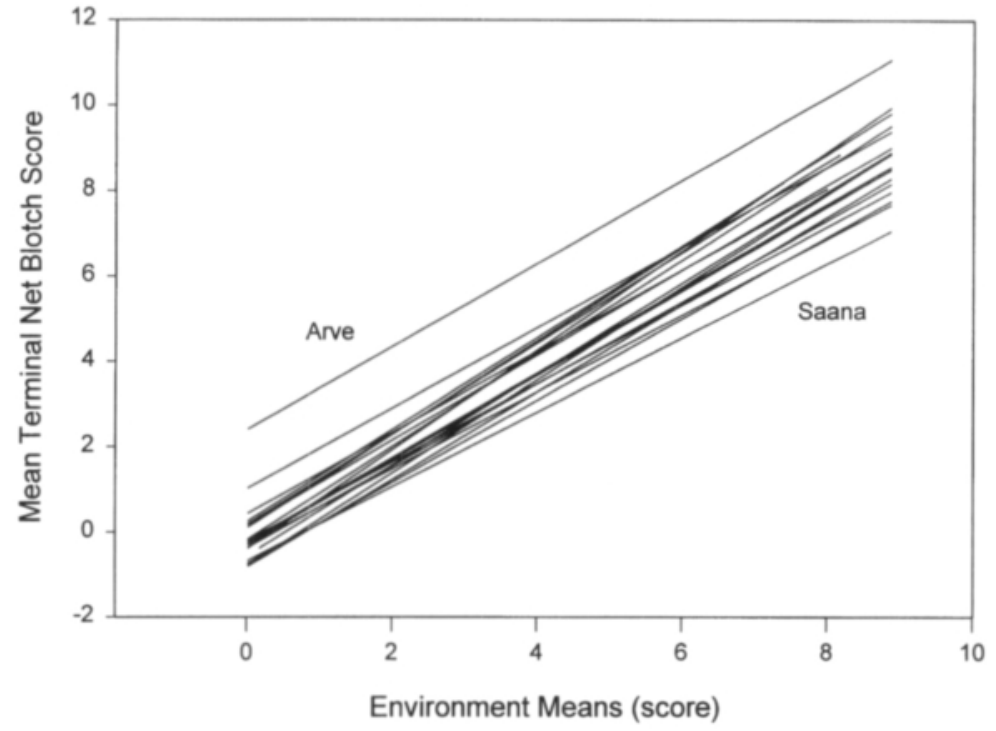

Fig. 4. Regressions for mean terminal net blotch severity scores of 19 spring barley genotypes on environmental means. Data are from Finnish official variety trials conducted at five sites over six years. 
Vol. 6 (1997): 399-408.

vironments. There is evidence that 'Saana' was symptomatically more resistant in most environments.

A plot of the regression coefficients from Figure 4 against mean net blotch scores for the individual barley genotypes (Fig. 5) indicates that most mean scores lie along the more resistant section of the $\mathrm{x}$-axis, around or below four. The mean score for 'Arve' occurs in the susceptible section, but its high net blotch score did not equate with a particularly low yield. 'Saana' exhibited a particularly stable (not sensitive) low mean response to net blotch, otherwise stable, resistant genotypes are represented by 'Pohto', 'Pokko' and 'Thule'. Coefficients of determination $\left(r^{2}\right)$ ranged between 0.88 and 0.97 .

Figure 6 represents the regression of May rainfall on mean terminal net blotch severity, where it can be noted that with increasing rainfall there is an increase in terminal net blotch severity. 'Arve' is characterised by its high level of infection, and there is evidence of crossover interaction. Individual regressions for genotypes, and for sites (four), were statistically significant $(\mathrm{P}<0.05)$. The mean regression for genotype was statistically significant $(\mathrm{df}=1,21 ; \mathrm{F}=70.04$; $\mathrm{P}<0.001$ ). Analysis of a dataset comprising the three genotypes 'Arra', 'Arve' and 'Pohto', grown in 53 environments, confirmed the nature of the relationship between May rainfall and terminal net blotch severity established with the reduced dataset (Fig. 7). The three individual regressions were statistically significant (for 'Arra', df = 1, 51; F = 47.13; $\mathrm{P}<0.001$ : for 'Arve', df $=1,51 ; \mathrm{F}=34.80 ; \mathrm{P}<0.001$ : for 'Pohto', $\mathrm{df}=$ $1,51 ; \mathrm{F}=46.30 ; \mathrm{P}<0.001)$ and differed significantly in intercept, but not in slope (comparing 'Arra' and 'Pohto'; for intercept, df =1, 111; F $=4.79 ; \mathrm{P}=0.03$ : for slope, $\mathrm{df}=1,111 ; \mathrm{F}=0.27$; $\mathrm{P}=0.61$. Comparing 'Arra' and 'Arve'; for intercept, $\mathrm{df}=1,108 ; \mathrm{F}=4.96 ; \mathrm{P}=0.03$ : for slope, $\mathrm{df}=1,108 ; \mathrm{F}=0.00 ; \mathrm{P}=0.97)$. There was no evidence of a quadratic regression fitting the data better than a linear regression $(\mathrm{P}>0.20)$.

May GDD regressed on mean terminal net blotch severity was statistically significant $(\mathrm{df}=$ $1,21 ; \mathrm{F}=27.03 ; \mathrm{P}<0.001)$ and negative $(\mathrm{y}=-$

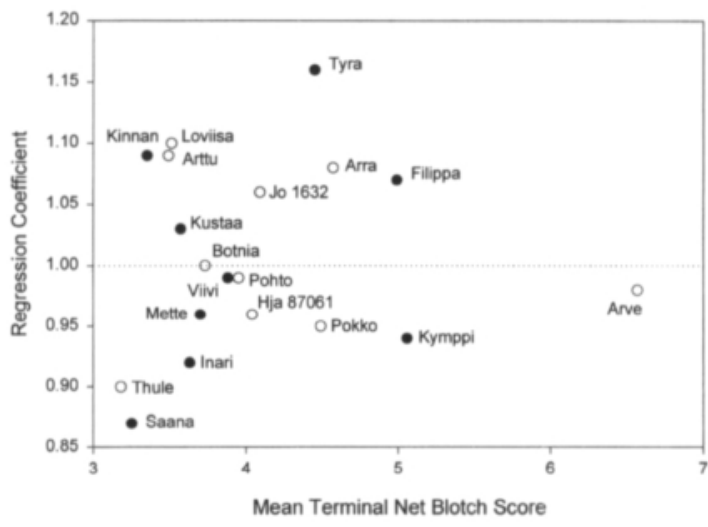

Fig. 5. Regression coefficients plotted against mean terminal net blotch severity scores for 19 spring barley genotypes grown in Finnish official variety trials conducted at five sites over six years. Solid circles represent 2-row barleys and open circles 6-row barleys.

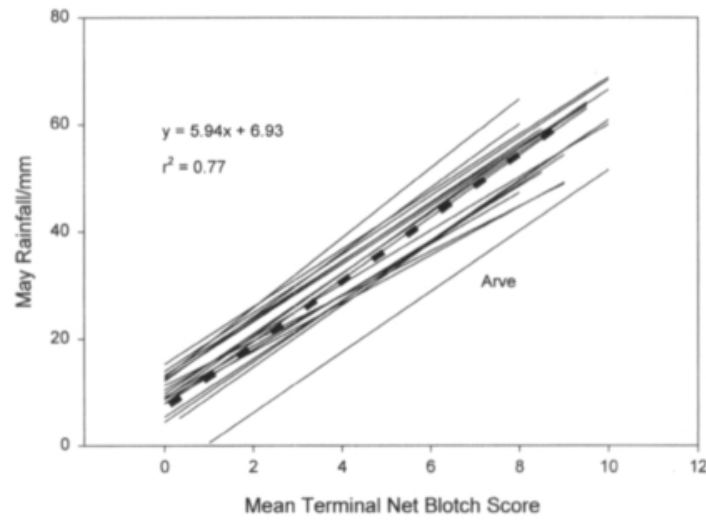

Fig. 6. Regression plots of May rainfall on terminal net blotch severity scores for 19 spring barley genotypes grown in Finnish official variety trials conducted at five sites over six years. The mean regression is represented by the broken line and the equation governing it, and the coefficient of determination are given.

$16.18 x+358.5)$. The data are not presented, but there was again indication of crossover interactions for the regressions for individual genotypes, and the line for 'Arve' was distinct from the rest. The coefficient of determination $\left(r^{2}=\right.$ $0.56)$ for the mean regression was smaller than that for the mean regression of May rainfall on net blotch severity $\left(r^{2}=0.77\right)$. Regression for 
Robinson, J. \& Jalli, M. Grain yield, net blotch and scald of barley

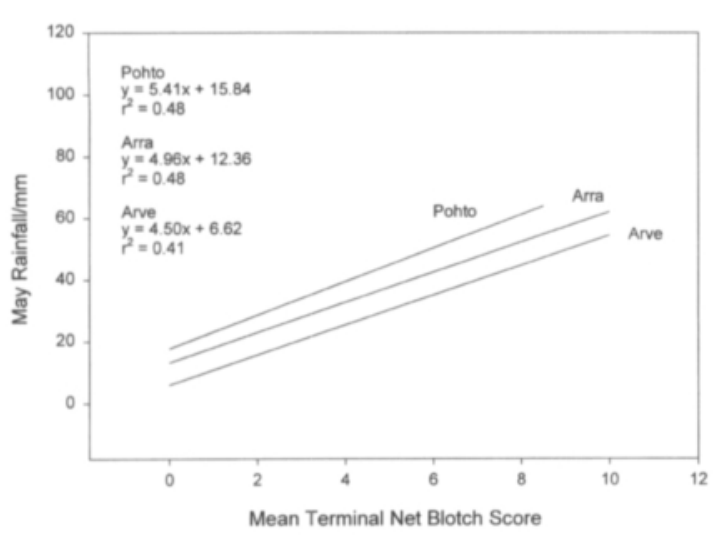

Fig. 7. Regression plots of May rainfall on terminal net blotch severity scores for three 6-row spring barley genotypes grown in Finnish official variety trials conducted in 53 environments. The equations for each regression and the coefficients of determination are given.

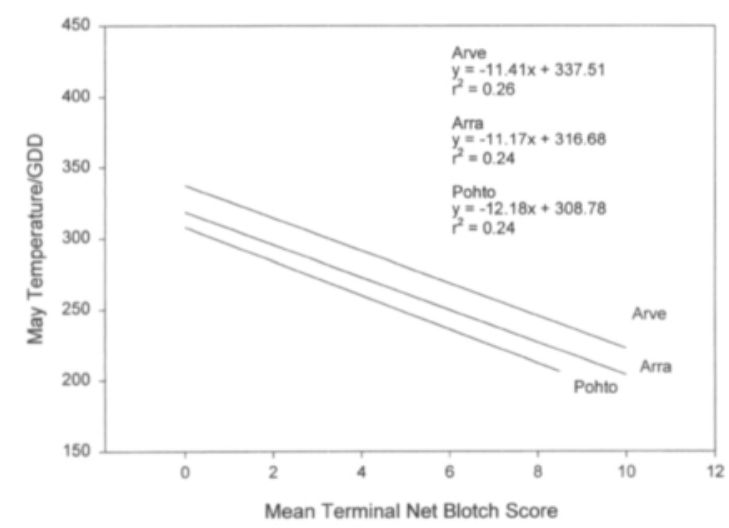

Fig. 8. Regression plots of May growing degree days (GDD) on terminal net blotch severity scores for three 6-row spring barley genotypes grown in Finnish official variety trials conducted in 53 environments. The equations for each regression and the coefficients of determination are given.

the dataset including 'Arra', 'Arve' and 'Pohto', confirmed these results (Fig. 8). There was, however, no statistically significant difference in intercept or slopes for the three individual lines $(\mathrm{P}>0.10)$. As for the May rainfall, GDD data regressed on net blotch severity fit linear models.

It was indicated that multiple regressions, incorporating both May rainfall and GDD, pro- vided slightly better fits than simple regressions, but given that the two factors were significantly correlated $(\mathrm{n}=53 ; \mathrm{r}=-0.51 ; \mathrm{P}<0.001)$, a bivariate analysis provided no greater insight into the effects than univariate ones.

Planting date of the trials did not have a statistically significantly effect on terminal net blotch severity $(P>0.05)$, and there were no statistically significant ties between either rainfall or GDD on terminal net blotch severity for months other than May. Neither May rainfall nor May GDD were correlated with final grain yields $(\mathrm{P}>0.05)$.

\section{Discussion}

The principal purpose of the Finnish official barley variety trials is to assess the value of new genotypes and make recommendations to growers, and breeders, on yield and quality parameters. Nissilä (1996) analysed datasets of barley yield from official variety trials conducted in Finland between 1970 and 1989 , with a view to establishing the significance of genotype by environment interaction and the consequences of it for barley breeding - whether to breed for wide or narrow adaptation. $\mathrm{He}$ attempted to establish the determinants of crossover interaction for yield among a range of barley genotypes by accounting for the differential effect of biotic and abiotic stresses on barley growth and yield. Factors including soil $\mathrm{pH}$, rainfall during the growing period and temperature patterns were found to be important. Disease resistance was also noted to influence the relationship between phenotype and genotype by environment interaction. The results of the analyses reported here are not in disagreement with the possibility that diseaseinduced stress is a determinant of yield capacity in barley, but the relationship between disease severity, in this instance net blotch and scald, and expressed as foliar symptoms, using a simple scoring procedure, and yield is not immediately obvious. 


\section{AGRICULTURAL AND FOOD SCIENCE IN FINLAND}

Vol. 6 (1997): 399-408.

Nissilä (1992) established a highly significant difference for barley grain yields between years, but no interaction between genotypes and years, and commented that a series of three years (and six genotypes) might not have been sufficient to determine its importance. For these data (Table 1) this interaction was important. Baker (1971) in a study of the effect of leaf and stem rust of wheat on yields in Canada indicated the statistical non-significance of the genotype by year interaction term. Nissilä (1992) moreover, proposed that the genotype by site interaction was more important than genotype by year interaction in barley breeding for Finnish conditions. It is statistically significant in this study also.

Scald, although considered an important disease of barley in Finland, was not as severe as net blotch in the variety trials (Fig. 3). Any breeding strategy for scald resistance, if the disease were serious enough to affect the economic yield of barley, would have to be done at sites where the disease is important. Robinson et al. (1996) reported that there were differences in quantitative resistance among six Nordic six-row spring barleys, when artificially inoculated in the field with scald. However, these data indicate that natural scald epidemics in the 29 environments studied were seldom severe enough to differentiate the genotypes sufficiently well to provide useful information to barley breeders and growers.

Net blotch appears to be the more prevalent of the two foliar diseases of barley and the data contained in Figure 2 indicate that it occurred at all the five sites studied and that the pattern of net blotch infection was similar at the five sites within any one year. This is interesting given the distance between the sites, and leads to speculation that some macro-climatic factor(s) determine its severity. For scald there are very definitely disease-prone environments, but for net blotch this appears not to be so, given the limitations of the sample dataset. This situation is likely to be a result of net blotch being comparatively less demanding of environmental conditions (mostly wind dispersed) than scald (most- ly splash dispersed) for effective spore dispersal and epidemic development.

One of the purposes of looking at this dataset was to determine if a relationship between disease severity and yield could be determined. For net blotch, there was not a significant regression of mean disease severity against mean yield for each of the 29 environments (year by site combinations) for specific genotypes, nor overall. However, when the dataset was expanded to include 59 environments, although unbalanced (data not shown), the linear regression was significant $(\mathrm{df}=1,56 ; \mathrm{F}=4.90 ; \mathrm{P}=0.03)$, although the $r^{2}$ value was only 0.06 . The nature of the relationship indicated however, that net blotch was more severe at higher yield levels. According to Baker (1990), disease incidence is assumed to be greater under environmental conditions conducive to higher yield. This appears to be the case for these data. It might therefore be more beneficial for growers and breeders alike to have yield data from disease-free plots so as to be able to estimate any yield loss associated with natural epidemics of barley diseases. Robinson and Jalli (1996) indicated that 'Arve' was particularly susceptible to net blotch under conditions of artificial inoculation in the field. H6221 (from which 'Thule' was derived) was noted to be resistant, and 'Arttu' and 'Pohto' were intermediate. This pattern appears to be reflected in the data contained in Figure 5 for infection under natural conditions.

Baker (1971) determined that the occurrence of two of the major diseases of wheat, stem and leaf rust, had a significant influence on the genotype by environment interaction component for wheat yield, and that this was due to differences in disease resistance among the wheat genotypes under study. There is no evidence from these results to suggest that something similar occurs for barley and its two major foliar pathogens in Finnish official variety trials. Whereas Baker (1971) determined that the component of variance for the genotype by site term was reduced considerably from an unadjusted to an adjusted value, this was not the case here and none of the genotype by site component of variance can be 


\section{Robinson, J. \& Jalli, M. Grain yield, net blotch and scald of barley}

attributed to variation in net blotch resistance among the barley genotypes. The data given in Table 1 indicate that analysis of mean grain yields adjusted for terminal net blotch severity had little effect on the mean squares and variance ratios over those calculated for unadjusted values. The error mean square was reduced from 0.11 to 0.10 and therefore the power of the test was not increased using a covariate as little of the error was due to variation in net blotch. Components of variance for genotype by year and genotype by site terms accounted for $4.1 \%$ and $6.0 \%$, and $3.1 \%$ and $5.4 \%$ of the total variance for unadjusted and adjusted data respectively.

The data indicate that differences in resistance to net blotch appear to exist among the 19 barley genotypes included in this study. However, as they cannot be linked directly with yield, and yield loss, they are not of immediately apparent value. For example, 'Arve' appears to be tolerant of net blotch; symptom expression is consistently higher on 'Arve' across all environments studied, than for any other genotype, and yet its yielding capacity was not diminished in comparison with that of the other barley genotypes. Symptom expression is misleading in this instance, although if the tolerance is real, it is potentially valuable to barley breeders. Dyke et al. (1995) considered that regression diagrams might occasionally be useful in revealing individual genotypes having special forms of disease susceptibility or resistance. 'Arve', with its symptomatic susceptibility to net blotch, appears to represent one such instance.

May rainfall and GDD influence the extent of terminal net blotch severity. All trials were sown in May, although sowing date as such was not correlated with terminal net blotch severity. Rainfall and temperature are naturally correlated and it can be surmised that sowing barley seed in a cool wet seed bed without a fungicide dressing increases the susceptibility of seedlings to infection from net blotch spores, possibly released from infected stubble remaining from the previous season. An additional possibility is that such conditions also allow seed-borne infection to develop to maximum effect. This, however, according to these data is a less probable explanation as seed dressing was discontinued beyond 1991, and reference to Figure 2 indicates that terminal net blotch severity in 1991 was high. There remains the possibility however that cool, wet conditions decrease the efficacy of seed dressings: the seed dressing may simply be washed off during heavy rainfall preceding emergence.

Useful work which might be done in the future with these datasets, and similar datasets, is to establish the extent and significance of crossover interaction for disease sensitivity, and determine the underlying reasons for it in terms of climatic and edaphic factors. In this way it might be established whether crossover interaction can be predicted, and therefore constitute useful information to barley breeders and growers. It may be necessary to modify the method of assessing disease severity in order to be better able to make an association with yield loss resulting from disease incidence. One shortcoming of the disease severity data is that they are collected solely at the end of the growing season and consequently it is impossible to comment on the timing of disease appearance and its progress through the season. If disease build-up occurs early in the season it is more likely to affect yield negatively than if it occurs late. An additional possibility is that some replicate blocks in the trials could be kept free of disease to allow comparison with yield under conditions of no disease. Disease severity could moreover be measured on samples of individual leaves throughout the growing season to allow identification of barley genotypes on which net blotch build-up is comparatively slow (James et al. 1968, Khan and D'Antuono 1985, Khan 1987).

Acknowledgements. These data were collected and compiled by a large number of staff from the Agricultural Research Centre of Finland. A. Kedonperä scored many of the trials for disease severity. S. Hyvärinen supplied the meteorological data. A. Järvi co-ordinated the trials and L. Mäkelä supplied the mean grain yield data with the assistance of I. Mattila. R. Aikasalo and E. Nissilä of Boreal Plant Breeding made useful comments on the work and T. Turpeinen is thanked for helping with data transfer. 
Vol. 6 (1997): 399-408.

\section{References}

Baker, R.J. 1971. Effects of stem rust and leaf rust of wheat on genotype-environment interaction for yield. Canadian Journal of Plant Science 51: 457-461.

- 1990. Crossover genotype-environmental interaction in spring wheat. In: Kang, M.S. (ed.). Genotype-byenvironment interaction and plant breeding. Louisiana State University Agricultural Center. p. 42-51.

Dyke, G.V., Lane, P.W. \& Jenkyn, J.F. 1995. Sensitivity (stability) analysis of multiple variety trials, with special reference to data expressed as proportions or percentages. Experimental Agriculture 31: 75-87.

Finlay, K.W. \& Wilkinson, G.N. 1963. The analysis of adaptation in a plant breeding programme. Australian Journal of Agricultural Research 14: 742-754.

James, W.C., Jenkins, J.E.E. \& Jemmet, J.L. 1968. The relationship between leaf blotch caused by Rhynchosporium secalis and losses in grain yield of spring barley. Annals of Applied Biology 62: 273-288.

Khan, T.N. 1987. Relationship between net blotch (Drechslera teres) and losses in grain yield of barley in Western Australia. Australian Journal of Agricultural Research 38: 671-679.

- \& D'Antuono, M.F. 1985. Relationship between scald (Rhynchosporium secalis) and losses in grain yield of barley in Western Australia. Australian Journal of Agricultural Research 36: 655-661.

Littell, R.C., Freund, R.J. \& Spector, P.C. 1991. SAS System for Linear Models. Third Edition, Cary, NC. 329 p.

Măkelä, K. 1974. Occurrence of Rhynchosporium secalis (Oud.) J.J. Davis on spring barley and winter rye in Finland. Journal of the Scientific Agricultural Society of Finland 46: 103-117.

- 1975. Occurrence of Helminthosporium species on cereals in Finland in 1971-1973. Journal of the Scientific Agricultural Society of Finland 47: 181-217.

Mathre, D.E. 1982. Compendium of barley diseases. American Phytopathology Society, St. Paul, Minnesota, USA. 78 p.

Mukula, J. 1988. The effect of climatic variations on barley yield. In: Parry, M.L. et al. (eds.). The Impact of
Climatic Variations on Agriculture, Vol. 1: Kluwer Academic Publishers. p. 547-583.

- \& Rantanen, O. 1989. Climatic risks to the yield and quality of field crops in Finland VI. Barley 1969-1986. Annales Agriculturae Fenniae 28: 29-36.

Nissilä, E. 1992. Yield stability of barley under Finnish conditions. Acta Agriculturae Scandinavica 42: 152157.

- 1996. Relationships between phenotype and genotype-environment interactions and their influence on yield in highly adapted barley germplasm. Ph.D. thesis, University of Helsinki, Finland. 107 p.

Robinson, J. \& Jalli, M. 1996. Diversity among Finnish net blotch isolates and resistance in barley. Euphytica 92: 81-87.

- , Lindqvist, H. \& Jalli, M. 1996. Genes for resistance to Finnish isolates of Rhynchosporium secalis. Euphytica 92: 295-300.

Saari, E.E. \& Prescott, J.M. 1975. A scale for appraising the foliar severity of wheat diseases. Plant Disease Reporter 59: 377-380.

Saarikko, R.A. \& Carter, T.R. 1996. Phenological development in spring cereals: response to temperature and photoperiod under northern conditions. European Journal of Agronomy 5: 59-70.

SAS Institute Inc. 1989. SAS/STAT User's Guide. Version 6, Fourth Edition, Volume 2, Cary, NC. 1686 p.

Shipton, W.A., Boyd, W.J.R. \& Ali, S.M. 1974. Scald of barley. Reviews in Plant Pathology 53: 839-861.

- , Khan, T.N. \& Boyd, W.J.R. 1973. Net blotch of barley. Reviews in Plant Pathology 52: 269-290.

Tottman, D.R. \& Makepeace, R.J. 1979. An explanation of the decimal code for the growth stages of cereals, with illustrations. Annals of Applied Biology 93: 221234.

Vivar, H.E., Burnett, P.A. \& Bowman, J.E. 1987. Breeding barley for multiple disease resistance. Barley Genetics V, Proceedings of the Fifth International Barley Genetics Symposium, Okayama, Japan. p. 615-623. 


\title{
AGRICULTURAL AND FOOD SCIENCE IN FINLAND
}

Robinson, J. \& Jalli, M. Grain yield, net blotch and scald of barley

\section{SELOSTUS}

\section{Ohrasato ja verkko- ja rengaslaikku virallisissa lajikekokeissa}

\author{
Jonathan Robinson ja Marja Jalli \\ Maatalouden tutkimuskeskus
}

Suomen virallisten lajikekokeiden ohrakokeiden (Hordeum vulgare L.) satotulokset ja verkkolaikun (Pyrenophora teres Drechs. $f$. teres Smedeg.) ja rengaslaikun (Rhynchosporium secalis (Oud.) J.J. Davis) määrä analysoitiin tautien esiintymisen määrittämiseksi sekä taudin, genotyypin ja ympäristön satovaikutuksen selvittämiseksi. Lisäksi tutkittiin sään vaikutusta verkkolaikun ankaruuteen.

Genotyyppi-koepaikka yhdysvaikutus oli tilastollisesti merkitsevä sadon mutta ei verkkolaikun esiintymisen suhteen. Verkkolaikun ankaruus vaihteli vuosittain mutta ei koepaikoittain. Verkkolaikun määrä kasvukauden lopussa oli suhteellisen pieni Saana- ja Thule-lajikkeilla eikä taudin esiintyminen ollut yhtä herkkä ympäristön vaikutukselle kuin esimerkiksi Tyra-lajikkeella. Arve oli oireiden perusteella alttein verkkolaikulle. Sen sato ei kuitenkaan kärsinyt taudin esiintymisestä, minkä vuoksi sitä voi pitää verkkolaikun kestäväna lajikkeena.
Satotulosten ja verkkolaikun ankaruuden analysointi osoittaa, että genotyypin ja ympäristön yhdysvaikutuksen suuruutta ei voi selittää ohragenotyyppien verkkolaikunkestävyyseroilla. Rengaslaikun ankaruuden keskiarvolukemat olivat yleisesti pienempiä kuin verkkolaikun, ja sen merkitys näyttää verkkolaikkua vähäisemmältä. Uusien koepaikkojen tulosten lisääminen verkkolaikkutuloksiin ei muuttanut tehtyä johtopäätöstä verkkolaikun runsaamman esiintymisen ja suuremman sadon yhteydestä. Toukokuun sademäärä ja lämpötilasumma $\left(\right.$ yli $\left.0^{\circ} \mathrm{C}\right)$ vaikuttivat verkkolaikun määrään ohrakasvustoissa kasvukauden lopussa. Ohran siementä ei Suomen virallisissa lajikekokeissa ole käsitelty kasvitautien torjunta-aineilla. Kylvö viileään ja märkään maahan näyttää edesauttavan ohran orasten verkkolaikkutartuntaa edellisvuonna tartunnan saaneesta kasvijätteestä vapautuvista verkkolaikkuitiöistä. Tulokset osoittavat, että kasvitautitulosten keräämistä virallisista lajikekokeista on kehitettävä. 